\title{
A bacterial facultative parasite of Gracilaria conferta
}

\author{
F. Weinberger ${ }^{1}$, M. Friedlander ${ }^{2}$, W. Gunkel ${ }^{1}$ \\ ${ }^{1}$ Biologische Anstalt Helgoland, Notkestrasse 31, D-22607 Hamburg, Germany \\ ${ }^{2}$ The National Institute of Oceanography, Tel Shikmona, PO Box 8030, Haifa 31080, Israel
}

\begin{abstract}
Bacterial epiphytes of Gracilaria conferta were quantified. Saprophytic bacteria reached 350 times and agar degraders 25000 times higher numbers $\mathrm{g}^{-1}$ algal wet wt on tissues infected with the 'white tips disease', as compared to healthy tissues. A bacterial inducing agent of the 'white tips disease' was detected. Addition of $10^{2}$ to $10^{3}$ cells of this isolate $\mathrm{ml}^{-1}$ medium led to increased rates of infection. This effect did not occur if the isolate was autoclaved before addition. The virulent bacteria could always be isolated from infected tissues. It frequently, but not always, infected $G$. conferta and should be regarded as a facultative parasite. Several factors influenced the disease development. Temperatures above $20^{\circ} \mathrm{C}$, in combination with photon flux densities of more than $200 \mu \mathrm{E} \mathrm{m}^{-2} \mathrm{~s}^{-1}$, increased the rate of infection. Relatively low amounts (more than $25 \mu \mathrm{g} \mathrm{ml}^{-1}$ ) of certain organic nutrients (peptone and yeast extract) led to strong manifestations of the disease. Addition of agar did not cause any symptoms, while $5 \mathrm{mg} \mathrm{l}^{-1}$ of the antibiotic rifampicin prevented the alga from being infected.
\end{abstract}

KEY WORDS: Gracilaria Bacteria - Epiphyte

\section{INTRODUCTION}

The red alga Gracilaria conferta (Schousboe) J. et G. Feldmann has been experimentally cultivated in Israel since 1984. Two diseases occurred during this time: the 'white tips disease' and the 'brown points disease'. Only the former has an economic impact.

The 'white tips disease' of Gracilaria conferta is distinguished by the fast development of white necrotic tissues, followed by thallus fragmentation (Fig. 1a, b). It only occurs from June to October, when $G$. conferta reaches its maximum growth rate (Friedlander \& Lipkin 1982) and it may lead to disintegration of nearly all algal biomass in a single tank. High densities of algal biomass and poor aeration (i.e. stress conditions; Friedlander \& Gunkel 1993) promote the disease.

The main symptom of 'brown points disease' is a tumour-like growth, leading to proliferations of nearly $1 \mathrm{~mm}$ diameter (Fig. 1c). Apt $(1984,1988)$ described a disease of Gracilaria epihippisora which led to similar symptoms and which was eventually found to be caused by a virus-like particle.
The main purpose of this work was to examine the bacterial flora of Gracilaria conferta for causative agents of 'white tips disease'.

\section{MATERIAL AND METHODS}

All experiments were carried out with strain SGSC-6 (Levy \& Friedlander 1990) of Gracilaria conferta. The algae were precultured in the laboratory at room temperature, artificial light ('cool white', $14 \mathrm{~h}$ light:10 h dark, $52 \mu \mathrm{E} \mathrm{s}^{-1} \mathrm{~m}^{-2}$ ) and strong aeration. Seawater was changed continuously ( 1 volume $\left.\mathrm{d}^{-1}\right)$. Nutrients were supplied by pulse feeding once a week. Cultivation of algae in experiments continued for 9,10 or $19 \mathrm{~d}$. Algal samples ( $2 \mathrm{~g}$ fresh wt $\mathrm{l}^{-1}$ medium) were put in test tubes or in Erlenmeyer flasks containing 20 or $50 \mathrm{ml}$, respectively, of Provasoli's ES-media (McLachlan 1973). The containers were kept at $25^{\circ} \mathrm{C}$ on shakers (100 strokes $\mathrm{min}^{-1}$ ) and exposed to $14 \mathrm{~h}$ of artificial light (cool white, $62 \mu \mathrm{E} \mathrm{m} \mathrm{m}^{-2} \mathrm{~s}^{-1}$ ) per day. Antibiotics and organic nutrients were taken from stock solutions Bacteria were precultured in fluid medium (recipe 


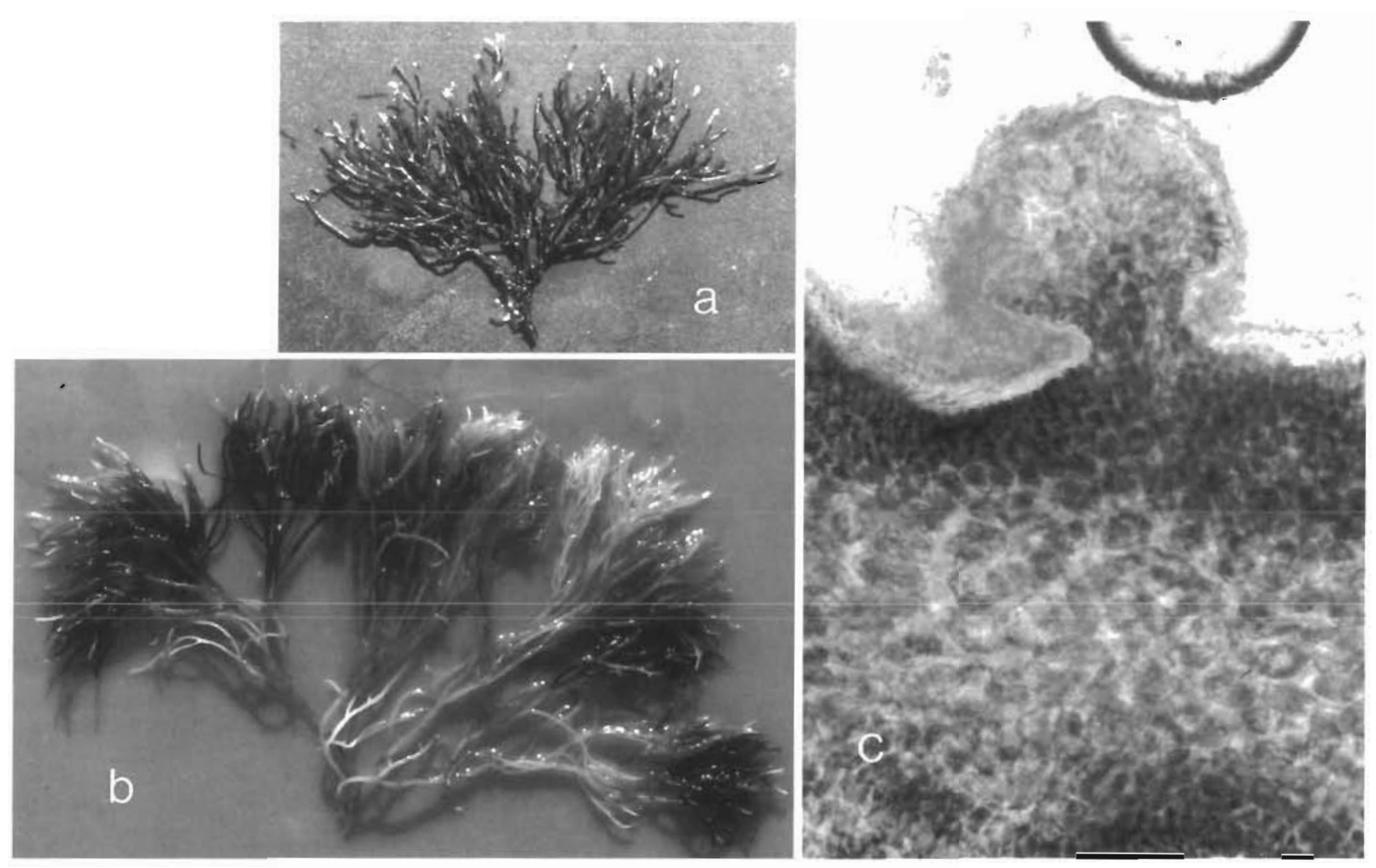

Fig. 1. Aspects of diseased Gracilaria conferta. (a) 'White tips disease', early stage. Only tips are bleached. Thallus length $6 \mathrm{~cm}$. (b) 'White tips disease', later stage. Whole branches are bleached. Thallus length $8 \mathrm{~cm}$. (c) 'Brown points disease' Longitudinal cut. A proliferation (diameter $0.5 \mathrm{~mm}$ ), covered by flocks of bacterial and microalgal epiphytes

below) for $72 \mathrm{~h}$. They were sedimented, before addition, by centrifugation and resuspended in autoclaved seawater, to eliminate dissolved organic substances.

All experiments were evaluated in the following manner. Diseased replicates $(D R)$ from all tubes $(N)$ were counted, as well as all algal tips $(A T)$ and white tips $(W T)$ in each diseased replicate. The relative number of white tips was calculated as

$$
\% W T=W T \times 100 / A T \text {. }
$$

A bleaching index $(B I)$ was finally calculated as

$$
B I=(D R / N) \% W T
$$

$B I$ reaches 100 if all tips in all replicates became white, and 0 if there were no symptoms visible at the end of the experiment.

Numbers of epiphytic bacteria were determined by homogenization and plating out of algal tissues on specific media in Petri dishes. Algal material (1 g) was homogenized for $15 \mathrm{~s}$ per $10 \mathrm{ml}$ of autoclaved, icecooled seawater with an ice-cooled homogenizer.

The plating out followed standard methods and was carried out on different types of medium. We used 2216E medium (Oppenheimer \& ZoBell 1952) for culti- vation of saprophytes: $1 \mathrm{~g}$ yeast extract (Difco), $5 \mathrm{~g}$ peptone (DifCo), $15 \mathrm{~g}$ bacto-agar (DifCo) and $0.01 \mathrm{~g}$ $\mathrm{FePO}_{4}$ were suspended in $1 \mathrm{l}$ of aged seawater and autoclaved. A modification of this medium, containing $0.5 \mathrm{~g}$ instead of $5 \mathrm{~g}$ of peptone and no yeast extract, allowed a better development of agar-degrading bacteria. 'Agar degraders' were considered to be those which either proliferated into the agar, forming depressions, or visibly liquefied it.

Colony-developing units on inoculated medium were counted after $1 \mathrm{wk}$ of incubation at $25^{\circ} \mathrm{C}$ in darkness. Their number in different homogenates was counted and correlated to the calculated $B I$ that resulted. They were differentiated by their shape, colour and size.

Examination of 100 different samples of algal tissue led to detection of 59 macromorphologically different colonies on medium 2216E. Cells from visually identical colonies were compared in microscopic examinations for cell size and shape, motility and Gramreaction. They were isolated and examined for their ability to grow on $2216 \mathrm{E}$ medium and agar-degraders medium. Thirty-one different kinds of colonies seemed to be always composed of cells with identical micro- 
morphological and physiological characteristics. They were regarded as 'differentiable types' of bacteria and counted separately. Differences in these data were analysed for significance, using Wilcoxon's rank sum test.

\section{RESULTS}

Table 1 presents total numbers of colonydevelopment units which were detected $\mathrm{g}^{-1}$ algal fresh wt. 1.5 to $3.9 \times 10^{5}$ colonies were found on healthy tips and healthy algae and about 200 times more $\left(3.3\right.$ to $\left.6.7 \times 10^{7}\right)$ on diseased algal tissues.

Agar degraders were remarkably rare on healthy tips $\left(5.6 \times 10^{2}\right)$, compared not only to white tips $\left(1.4 \times 10^{7}\right)$, but also to healthy algae $\left(1.4 \times 10^{4}\right) .3 .9 \times 10^{5}$ agar degraders were found on plants with brown points (tumourous algae).

Numbers of differentiable bacteria types on healthy and white tips are presented in Fig. 2. The results show that bacteria on healthy and bleached tips differed significantly, with probabilities $>50 \%$. Maximum differences were reached by OR-I1, OR-R1 and Y-I4, with probabilities of $100 \%$. Only Y-R1 did not differ significantly on healthy and white tips (probability for differences only $33.1 \%$.

Four types were exclusively detected on healthy tips; all of them reached less than 1000 colony-developing units $\mathrm{g}^{-1}$ algal fresh wt. Bacteria numbers of this order were unrecognizeable in bleached tissues, since the total number of bacteria was too high.

Nine types were exclusively detected on white tips. Seven of them (Y-I5, OR-I1, OR-I2, TR-I3, Y-R7, Y-I4 and W-R8) were able to degrade agar.

All of the remaining 11 differentiable types, which were found on healthy as well as on bleached tips, reached higher numbers on diseased tissue. Only 2 of them were agar degraders (Y-R1 and W-R5).

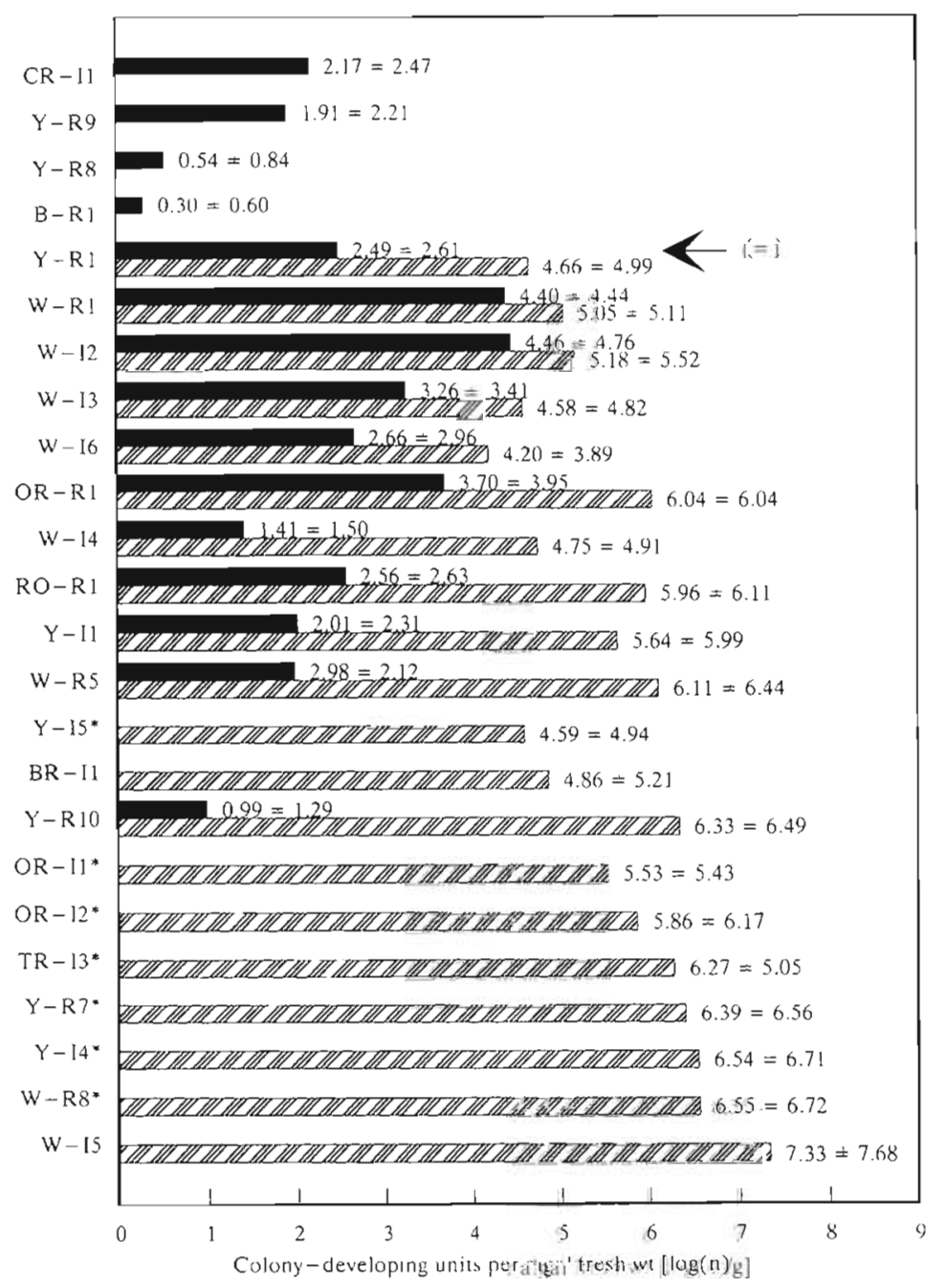

Fig. 2. Number of differentiable types of epiphytic bacteria on Gracilaria conferta. Solid bars: colony-developing units found on healthy tips ( $n=15$ ). Hatched bars: colony-developing units found on bleached tips $(n=18)$. Average \pm standard deviation of the mean are given to the right of each bar. Arrow and (=) indicates bacteria type which reached probabilities of difference of less than $50 \%$ in a Wilcoxon's rank sum test, comparing data for healthy and diseased tissues. ' : agar degrader

Fig. 3 summarizes numbers of colony-developing units of 23 types, which were found on thalli with and without tumours. Three types were not found and 10 types were exclusively found on diseased plants.

Table 1. Total numbers $(\bar{x} \pm S D)$ on colony-developing units $g^{-1}$ fresh wt of epiphytic saprophytes and agar degraders on healthy and diseased Gracilaria conferta

\begin{tabular}{|c|c|c|c|}
\hline Source & Replicates & Saprophytes & Agar degraders \\
\hline Healthy tips & 15 & $1.53 \times 10^{5} \pm 2.41 \times 10^{5}$ & $5.57 \times 10^{2} \pm 2.97 \times 10^{2}$ \\
\hline White tips & 18 & $6.72 \times 10^{7} \pm 7.10 \times 10^{7}$ & $1.38 \times 10^{7} \pm 1.07 \times 10^{7}$ \\
\hline Healthy algae & 12 & $3.91 \times 10^{5} \pm 2.53 \times 10^{5}$ & $1.44 \times 10^{4} \pm 3.10 \times 10^{4}$ \\
\hline Tumourous algae & 39 & $3.33 \times 10^{7} \pm 2.70 \times 10^{7}$ & $3.91 \times 10^{5} \pm 5.23 \times 10^{5}$ \\
\hline
\end{tabular}




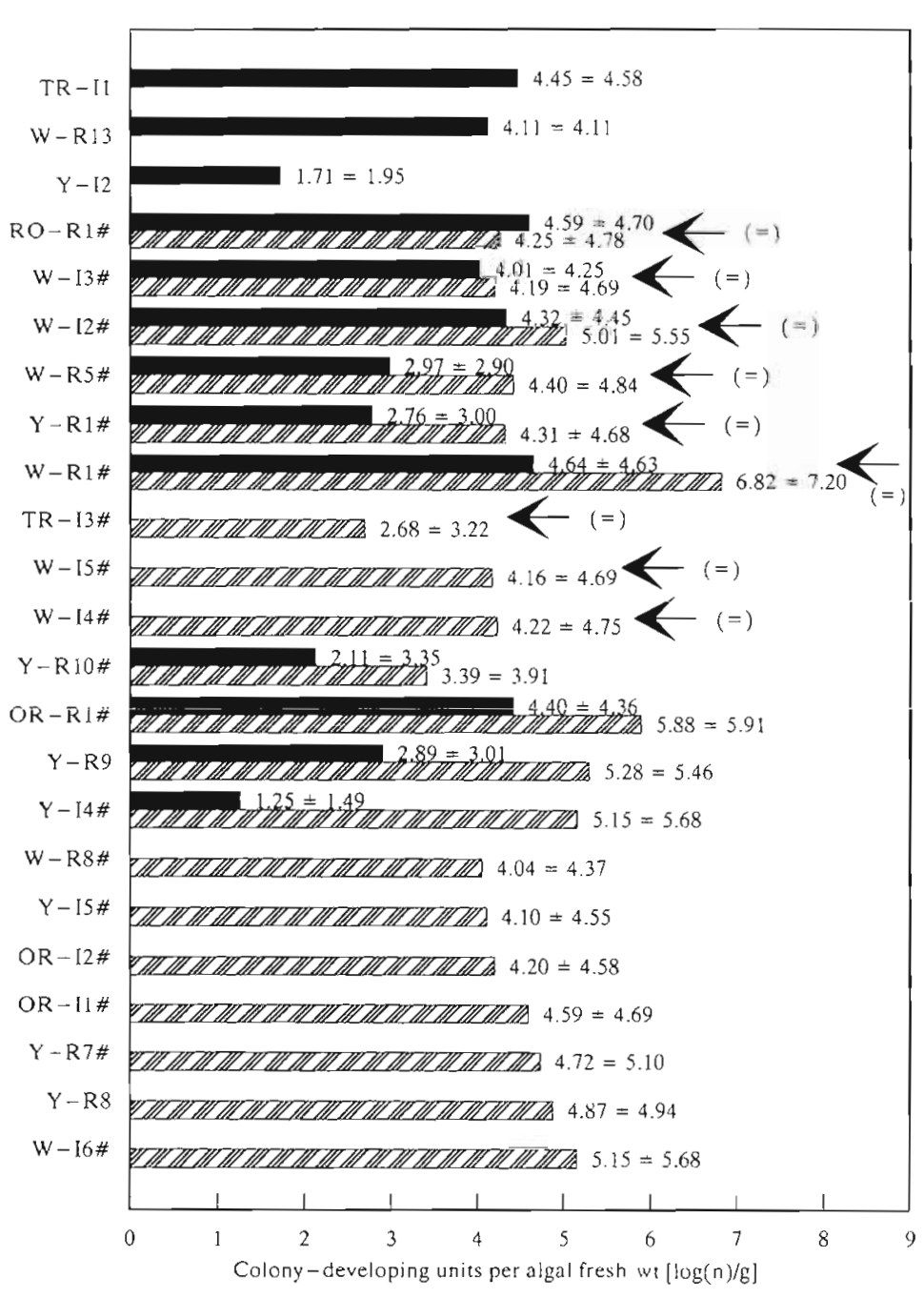

Fig. 3. Number of differentiable types of epiphytic bacteria on Gracilaria conferta. Black bars: colony-developing units found on healthy plants ( $n=12$ ). Hatched bars: colony-developing units found on tumourous plants $(n=39)$. Average \pm standard deviation of the mean are given to the right of each bar. Arrow and $(=)$ indicates bacteria type which reached probabilities of difference of less than $50 \%$ in a Wilcoxon's rank sum test, comparing data for healthy and diseased tissues. \#: also detected on bleached tips

Seven of the latter (Y-R7, TR-I3, W-R8, Y-I5, W-I5, OR-I1 and OR-I2) were also detected on bleached, but not on healthy, tips.

Wilcoxon's rank sum test demonstrated that occurrence of 14 types of bacteria differed on plants with and without brown spots, with probabilities $>50 \%$. The probability of difference reached $100 \%$ for Y-R8 and $>99 \%$ for OR-I1, OR-R1 and Y-R7, Data of 9 types (W-I2, W-I3, W-I4, W-I5, W-R1, W-R5, Y-R1, TR-I3 and RO-R1) did not differ, with probabilities $<50 \%$ for difference.

Nine different antibiotics were tested for inhibiting effects on the occurrence of white tips. Gracilaria conferta was cultured for $10 \mathrm{~d}$ under stress conditions. One addition of $10 \mathrm{mg} \mathrm{l}^{-1}$ rifampicin at the beginning of the experiments reduced the percentage of diseased cultures from 92.6 to $51.9 \%$ (Table 2). Weekly addition of $5 \mathrm{mg} \mathrm{l}^{-1}$ reduced the percentage even further (from 96.3 to $40.7 \%$, Table 2 ).

Addition of $10 \mathrm{mg} \mathrm{l}^{-1}$ of erythromycin or chloramphenicol reduced the probability of disease appearance, but showed toxic sideeffects, causing disintegration in large parts of the Gracilaria conferta thallus. No effects on the occurrence of white tips could be detected when mycostatin (nystatin), neomycin, penicillin, polymyxin B or streptomycin sulfate were added.

Peptone, agar and yeast extract were tested for their effects on the occurrence of white tips. Typical results are presented in Table 3. Very few plants showed white tips without the addition of organic nutrients. The addition of peptone (250 to $5000 \mathrm{mg} \mathrm{l}^{-1}$ ) to the culture media led to bleaching of more than $75 \%$ of all tips. With the addition of smaller amounts of peptone $(25$ and $50 \mathrm{mg}$ $\left.1^{-1}\right) 50 \%$ of the tips still showed bleaching symptoms. Addition of yeast extract $(50 \mathrm{mg}$ $1^{-1}$ ) bleached $75 \%$ of all tips. In contrast, comparable amounts of agar ( 5 to $500 \mathrm{mg} \mathrm{I}^{-1}$ ) did not cause the appearance of white tips.

Cultivation of healthy plants for $19 \mathrm{~d}$ led to a $B I$ of 7.63 . This rate could be modified by addition of $1.75 \mathrm{~g}$ of different homogenized algal tissue $\mathrm{l}^{-1}$ medium (Table 4 ). Addition of healthy tissue, tissue with white tips and tissue with tumours (brown points) increased the $B I$ to $22.57,44.44$ and 52.08 , respectively, showing that infected algae led to the strongest effect. Freezing and slow thawing of homogenates before addition - a treatment which reduced the number of bacteria by a factor of $1 \times 10^{4}$ - caused a remarkable decrease of the $B I$ to 0 to 3.17 .

Table 2. Influences of rifampicin on the occurrence of white tips in cultures of Gracilaria conferta after $10 \mathrm{~d}$. Percentage of disease replicates $(n=27)$ is given

\begin{tabular}{|cc|}
\hline Treatment & $\%$ diseased replicates \\
\hline Addition at the beginning of the experiment: \\
Distilled water & $92.6 \%$ \\
Rifampicin $10 \mathrm{mg} \mathrm{l}^{-1}$ & $51.9 \%$ \\
Addition at the beginning and a second time after $7 \mathrm{~d}$ : & $96.3 \%$ \\
Distilled water & $40.7 \%$ \\
Rifampicin $5 \mathrm{mg} \mathrm{l}^{-1}$ & \\
\hline
\end{tabular}


Table 3. Gracilaria conferta. Effect of organic nutrient additions on the percentage of white tips $(\% W T \pm$ standard deviation) in algal cultures, after $9 \mathrm{~d}$

\begin{tabular}{|lccc|}
\cline { 2 - 4 } Nutrient & Replicates & $\begin{array}{c}\text { Concentration } \\
\left(\mathrm{mg} \mathrm{l}^{-1}\right)\end{array}$ & $\begin{array}{c}\% W T \\
(\overline{\boldsymbol{X}} \pm \mathrm{SD})\end{array}$ \\
\hline None & 6 & 0 & $7.7 \pm 11.68$ \\
Peptone & 3 & 5000 & $100.0 \pm 0$ \\
Peptone & 3 & 500 & $84.4 \pm 22.0$ \\
Peptone & 3 & 250 & $100 \pm 0$ \\
Peptone & 3 & 50 & $58.3 \pm 18.0$ \\
Peptone & 3 & 25 & $55.6 \pm 41.57$ \\
Yeast extract & 3 & 50 & $75 \pm 20.41$ \\
Agar & 3 & 500 & $0 \pm 0$ \\
Agar & 3 & 50 & $0 \pm 0$ \\
Agar & 3 & 5 & $0 \pm 0$ \\
\hline
\end{tabular}

No plants were diseased if the homogenate was filtered (mesh size $0.2 \mu \mathrm{m}$ ) before addition. This procedure reduced the number of microorganisms by $7 \times 10^{4}$

Treatments of algal cultures with algal homogenates, which reduced the number of bacteria, also reduced manifestations of the disease. This was not due to a reduction of the total number of saprophytes, but to a reduction in the number of certain bacteria types. The total number of saprophytes in the homogenates showed a negative correlation with $B I(p<0.05$; Table 5), while the number of bacteria of Y-I4, OR-I1, Y-R8, W-I2 and W-I5 types showed a positive correlation $(\mathrm{p}<0.01)$.

Different types of bacteria were isolated from bleached tips, propagated and added to algal cultures. Only the addition of OR-I1 caused reproductive positive effects on the occurrence of 'white tips disease'. Fig. 4 shows the effect of different amounts of this type on $B I$. Addition of $1.39 \times 10^{\circ}$ cells $\mathrm{ml}^{-1}$ medium led to $B I$ s of not more than 1.4. Addition of $1.79 \times 10^{1}$ to $1.79 \times 10^{5}$ cells $\mathrm{ml}^{-1}$ caused $B I$ s ranging from 18.0 to a maximum of 60.3 . Addition of $2.11 \times 10^{7}$ cells $\mathrm{ml}^{-1}$ led

Table 4. Gracilaria conferta. Effects of different algal homogenates (1.75 $\mathrm{g} \mathrm{l}^{-1}$ medium) on the bleaching index $(B I)$, after $19 \mathrm{~d}$

\begin{tabular}{|lrc|}
\hline Type of homogenate & $\mathrm{n}$ & $\begin{array}{c}B I \\
(\bar{x} \pm \mathrm{SD})\end{array}$ \\
\hline No homogenate & & $7.63 \pm 3.71$ \\
Healthy tissue & 9 & $22.57 \pm 20.18$ \\
Healthy tissue, frozen & 9 & $3.17 \pm 0.00$ \\
Tissue with white tips & 15 & $44.44 \pm 9.69$ \\
Tissue with brown points & 36 & $52.08 \pm 22.35$ \\
Frozen tissue with brown points & 3 & $0.00 \pm 0.00$ \\
Filtered $(0.2 \mu \mathrm{m})$ tissue & & \\
$\quad$ with brown points & 9 & $0.00 \pm 0.00$ \\
\hline
\end{tabular}

Table 5. Gracilaria conferta. Pearson-correlation coefficients between the bleaching index affected by different algal homogenates $\left(1.75 \mathrm{mg} \mathrm{ml}^{-1}\right.$ medium) and the number of colony-developing units of bacteria which was found in the homogenates

\begin{tabular}{|lcc|}
\hline Type & $\mathrm{r}$ & $\mathrm{p}$ \\
\hline Y-I4 & 0.66765 & $<0.001$ \\
OR-I1 & 0.49982 & $<0.001$ \\
Y-R8 & 0.19652 & $<0.005$ \\
W-I2 & 0.18375 & $<0.01$ \\
W-I5 & 0.17884 & $<0.01$ \\
Saprophytes in toto & -0.13856 & $<0.05$ \\
\hline
\end{tabular}

to a high degree of disease $(B I=47.7)$. There was a distinct gap in the effect if $2.11 \times 10^{6}$ cells $\mathrm{ml}^{-1}$ were added $(B I=4.1)$. Addition of dead (autoclaved) cells of OR-I1 caused no white tips.

Fig. 5 shows the percentage of tip bleaching and number of reisolated bacteria of OR-I1, $9 \mathrm{~d}$ after infection with different numbers of OR-I1 bacteria. No bleaching took place when no bacteria were added. Addition of $8 \times 10^{6}$ and $8 \times 10^{9}$ cells $g^{-1}$ algal wet wt caused 83.33 and $90.00 \%$ of white tips respectively. Supply of $8 \times 10^{8}$ cells g ${ }^{-1}$ (equal to $1.5 \times 10^{6}$ cells ml $^{-1}$ medium) led to bleaching of only $12.22 \pm 10.72 \%$ of all tips.

The type OR-I1 could not be detected when it had not been added (Fig. 5). It was, however, always found if addition had taken place. Increasing numbers of added bacteria were reflected in increasing numbers of reisolated bacteria: $4.24 \times 10^{6}, 5.30 \times 10^{6}$ and $5.31 \times 10^{7}$ bacteria $\mathrm{g}^{-1}$ were found on tips where $8 \times 10^{6}, 8 \times 10^{8}$ and $8 \times 10^{9}$ cells g $^{-1}$ algal wet wt had

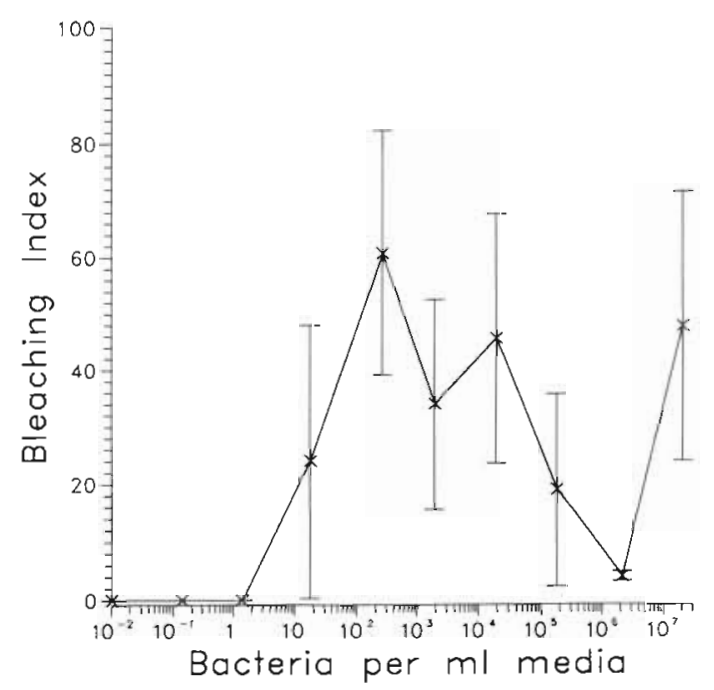

Fig. 4. Effect of the number of added cells of type OR-I1 on the bleaching index of Gracilaria conferta tips, after $9 \mathrm{~d}$. Error bar $=\mathrm{SD}$ 


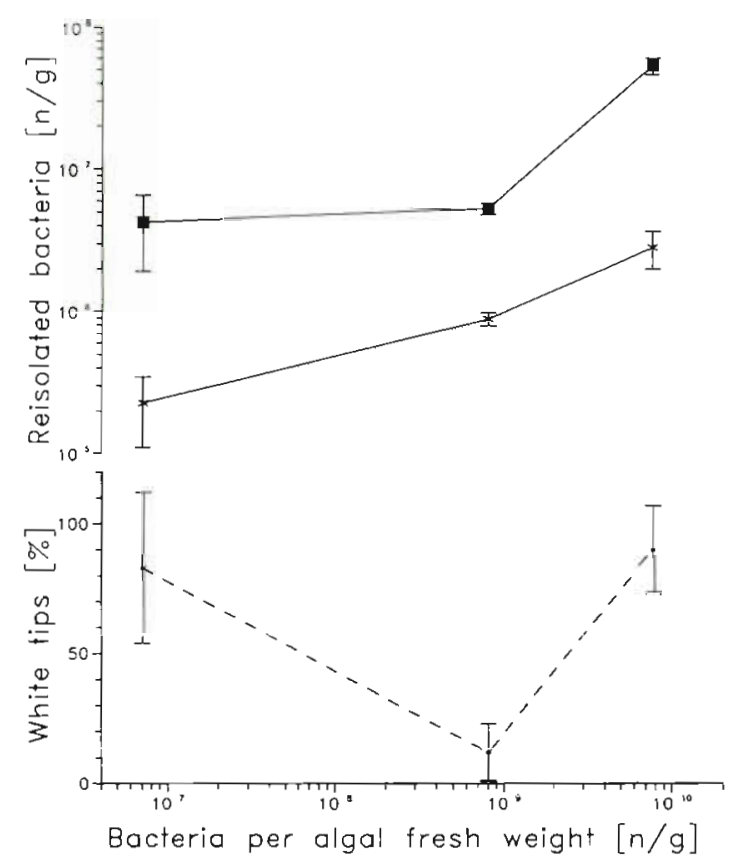

Fig. 5. Gracilaria conferta. Percentage of white tips (- - -) and number of reisolated bacteria of type OR-I $19 \mathrm{~d}$ after addition to algal cultures (-), as a function of OR-I1 bacteria. (घ) Bacteria reisolated from algal tips; $(x)$ bacteria reisolated from algal tissue without tips

been added respectively. Six to nineteen times higher numbers of OR-I1 were detected on tips when compared to remaining algal parts; $2.28 \times 10^{5}, 8.83 \times 10^{5}$

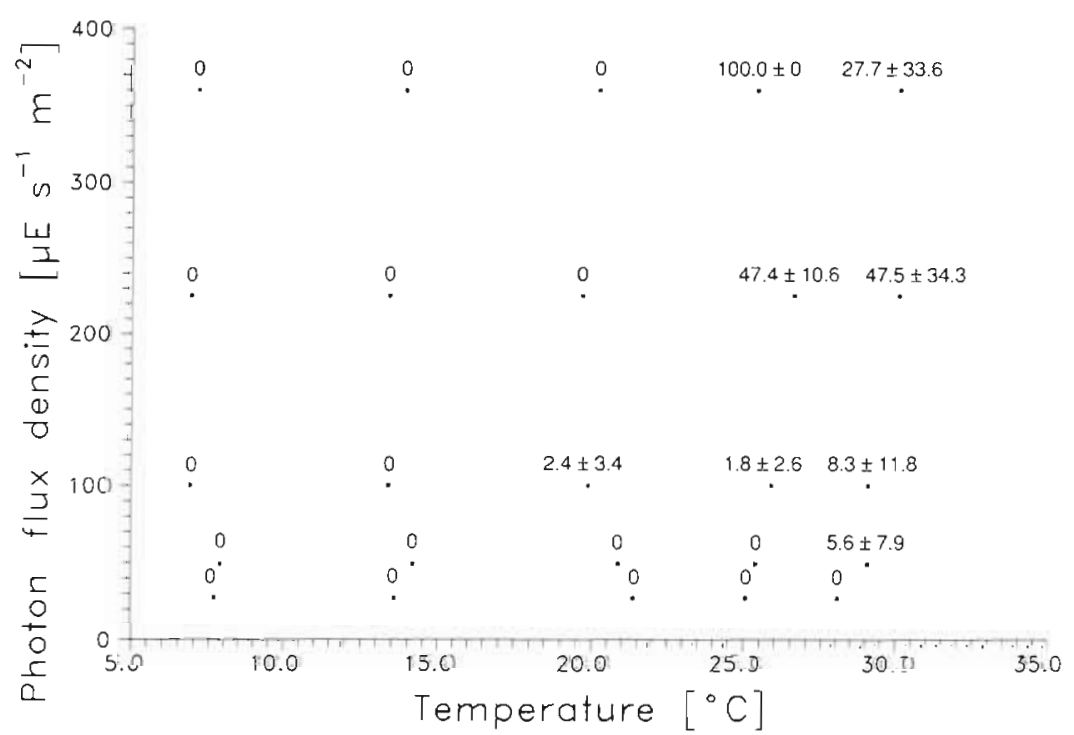

Fig. 6. Influence of different combinations of temperature and photon flux density on tip bleaching of Gracilaria conferta $19 \mathrm{~d}$ after addition of $1.05 \times 10^{6}$ cells of type OR-I1 mL $\mathrm{m}^{-1}$ medium. Each asterisk represents 3 replicates which grew in similar temperature and light conditions on a growth gradient table. Average \pm standard deviation of the percentage of white tips is given. No bleaching occurred when no bacteria were added and $2.83 \times 10^{6}$ bacteria $^{-1}$ were found on algal thalli without tips. About $10^{6}$ cells of OR-I $1 \mathrm{ml}^{-1}$ medium caused remarkably less bleaching than when lower numbers were added, if the algae were kept under standard conditions (Figs. 3 \& 4).

Modifications in photon flux density and temperature affected the rate of bleaching. Fig. 6 shows the effect of $1.05 \times 10^{6}$ cells ml ${ }^{-1}$ of OR-I1 on the percentage of white tips, after $19 \mathrm{~d}$ of cultivation on a growth gradient table. White tips (up to $100 \pm 0 \%$ ) developed at temperatures above $25^{\circ} \mathrm{C}$. Increasing photon flux densities caused increasing relative numbers of white tips. Temperatures above $25^{\circ} \mathrm{C}$, in combination with photon flux densities above $200 \mu \mathrm{E} \mathrm{m} \mathrm{m}^{-2} \mathrm{~s}^{-1}$, always caused $27.78 \%$ of white tips or more. Under all temperature and light conditions tested, no effects were found when no bacteria were added.

\section{DISCUSSION}

Quantification of bacterial epiphytes of Gracilaria conferta showed that healthy individuals carried $6 \times$ $10^{4}$ to $7 \times 10^{5}$ bacteria $g^{-1}$ algal fresh wt, and 10 times more bacteria $\left(5 \times 10^{5}\right.$ to $\left.7 \times 10^{6}\right)$ could be estimated $g^{-1}$ dry matter. This agrees with the results of Chan \& McManus (1969) for Polysiphonia lanosa $\left(10^{6}\right.$ to $10^{7}$ bacteria $\mathrm{g}^{-1}$ dry wt).

On disintegrating parts of Gracilaria conferta, 440 times more saprophytes were detected than on healthy tissue. High numbers of bacteria have been previously determined on decaying algal biomass (Wolter \& Rheinheimer 1977, Albright et al. 1980). Agar degraders reached 34000 times higher numbers on disintegrating tissues than on healthy ones, showing higher virulence as compared to saprophytes. Nine bacteria types, including 7 agar degraders, were detected exclusively on white tips. Other types, which grew on healthy tips, reached, in most cases, higher numbers on white tips.

Proliferations lead to an irregular algal surface, which is a better substrate for colonization by epiphytic microalgae and bacteria (Weinberger 1991). It is, therefore, not surprising that 85 times more saprophytes $\mathrm{g}^{-1}$ algal wet wt grew on algae with tumours, as compared to healthy plants, while agar degraders increased only slightly (16 times). 
Occurrence of white tips was inhibited by rifampicin, an inhibitor of procaryotic RNA-polymerase, which indicates the participation of bacteria in induction of the disease. Addition of similar amounts of homogenized algae to cultures of Gracilaria conferta induced white tips in different intensities, depending on the homogenate type. Freezing or filtration reduced the contents of bacteria in homogenates by $10^{4}$ to $10^{5}$ times and inhibited the disease-causing effects. The total number of saprophytes was negatively correlated with disease-causing effects. However, certain types such as OR-I1 and Y-I4, and to a lesser extent other types, showed positive correlation between the number of bacteria and disease-causing effects.

These findings indicate that one of these types must be the infective agent for white tips. On a large scale of experiments only OR-I1 regularly led to manifestations of the disease. Addition of relatively low amounts $\left(10^{2}\right.$ to $\left.10^{3} \mathrm{ml}^{-1}\right)$ always caused white tips. This effect did not occur if dead (autoclaved) cells were added. Koch's second postulate, which demands the infectivity of biotic disease-causing agents, seems therefore to be fulfilled by OR-I1.

Addition of $10^{6}$ cells of this type led to less intense degrees of the disease, though high numbers of cells of OR-I 1 could be detected after $9 \alpha$. Temperatures above $25^{\circ} \mathrm{C}$, particularly in connection with photon flux densities above $200 \mu \mathrm{E} \mathrm{m}^{-2} \mathrm{~s}^{-1}$, cancelled this diminution of infectivity. The mean occurrence of the infection in summer (Friedlander \& Gunkel 1992) agrees with the influence of strong light and high temperature in the experiment. It remains unclear which mechanisms lead to the effect of high temperatures, high photon flux densities or other ecological factors (e.g. stress conditions), as well as to the reduction in the infectivity after addition of $10^{6}$ cells.

It could be hypothesized that certain components of the bacterial epiphyton have a stabilizing effect on healthy Gracilaria conferta, preventing infections with OR-I1. Bactericidal effects of bacteria growing on seaweeds are well documented (Lemos et al. 1985) and antibiotically active types were detected on Gracilaria sp. (Weinberger 1991).

Low amounts of peptone and yeast extract caused strong infections. Nutrients of this type - proteins or amino acids - are easy to degrade and thus relatively rare on the algal surface. It may be that their supply can affect the bacterial epiphyton through selective advantage. This could lead to disturbances in the protective quality of the epiphyton and could cause further infections.

Agar, in contrast, is continuously exuded by Gracilaria conferta. It cannot be regarded as a limiting factor to epiphytic organisms. Addition should, therefore, not cause remarkable shifts in the bacterial flora. This agrees with the fact that agar did not cause infections.

The type OR-I1 was isolated regularly from previously infected algae, meeting the third of Koch's postulates. In all cases of apparently unsuccessful infection with OR-I1 it could still be reisolated after $9 \mathrm{~d}$. It was found to be conspicuously numerous on the tips, its potential site of infection.

The type OR-I1 was further isolated from tumourbearing algae in densities of $3.85 \times 10^{4} \mathrm{~g}^{-1}$ wet wt without causing white tips. The mechanism that prevents infection in tumourous, probably weakened, plants has not yet been found.

Our results indicate that the type OR-I1 is a facultative parasite of Gracilaria conferta. 'White tips disease' is linked to the presence of this isolate, but it can only become virulent under certain ecological conditions.

\section{LITERATURE CITED}

Albright, L. J., Chocair, J., Masuda, K., Valdés, M. (1980). In situ degradation of the kelps Macrocystis integrifolia and Nereocystis luetkeana in British Columbia coastal waters. Nat. can. 107: 3-10

Apt, K. E. (1984). Tumour-like growths on Gracilaria epihippisora Hoyle. J. Phycol. 24(Suppl.): 24

Apt, K. E. (1988). Galls and tumor-like growths on marine macroalgae. Dis. aquat. Org. 4: 211-217

Chan, E. C. S., McManus, E. A. (1969). Distribution, characterisation and nutrition of marine microorganisms from the algae Polysiphonia lanosa and Ascophyllum nodosum. Can. J. Microbiol. 15: 409-420

Friedlander, M., Gunkel, W. (1992). Factors leading to thallus disintegration and the control of these factors in Gracilaria sp. In: Moav, B., Hilge, B., Rosenthal, H. (eds.) Proceedings of the 4 th German-Israeli Status Seminar. EAS Special Publication No. 17, Oostende, p. 221-243

Friedlander, M., Lipkin, Y. (1982). Rearing of agarophytes and carrageenophytes under field conditions in the Eastern Mediterranean. Botanica mar. 25: 101-105

Lemos, M. L., Toranzo, A. E., Barja, J. L. (1985). Antibiotic activity of epiphytic bacteria isolated from intertidal seaweeds. Microb. Ecol. 11: 149-163

Levy, I., Friedlander, M. (1990). Strain selection in Gracilaria spp. I. Growth, pigment, and carbohydrates characterization of strains of $G$. conferta and $G$. verrucosa (Rhodophyta, Gigartinales). Botanica mar. 33: 339-345

McLachlan, J. (1973). Growth media - marine. In: Stein, J. (ed.) Handbook of phycological methods. University Press, London, p. 25-51

Oppenheimer, C. H., ZoBell, C. E. (1952). The growth and viability of sixty-three species of marine bacteria as influenced by hydrostatic pressure. J. mar. Res. 11: 10-18

Weinberger, F. (1991). Untersuchungen über den Einfluss epiphytischer Bakterien und Hefen auf den Zerfall ('disintegration disease') der Alga Gracilaria sp. (Rhodophyta). Diplomarbeit, Universität Hamburg

Wolter, K., Rheinheimer, G. (1977). Bakteriologische Untersuchungen an in der Brandungszone angetriebenem Algenmaterial, Botanica mar. 20: 171-181 